\title{
Interpersonal Relationships of Juvenile Offenders at Treatment Facilities,***
}

\author{
Vinicius Coscioni ${ }^{* * *}$ (®, Danielly Bart do Nascimento (®, Edinete Maria Rosa (®) \\ \& Sílvia Helena Koller (1)
}

Universidade Federal do Rio Grande do Sul, Porto Alegre, RS, Brasil

\begin{abstract}
This research characterized interpersonal relationships established by juvenile offenders at treatment facilities, from the juvenile offenders' perspective. It is a multiple case study conducted through four focus groups with 25 juvenile offenders, aged from 15 to 19 years old, inmate in treatment facilities of two Brazilian States. Participants characterized relationships with the treatment facilities' workers as hostile and distant. Relationships with peers were mediated by values that perpetuate offending behavior. Adolescents related an approach with their families, as they were a source of social support during the moment of adversity. The period in treatment facilities thus constitutes a time of intense suffering and ineffective in its function of promoting development.
\end{abstract}

KEYWORDS: adolescent, institutionalized, juvenile delinquency, interpersonal relationships

\section{Relações Interpessoais de Adolescentes em Medida Socioeducativa de Internação}

\begin{abstract}
RESUMO - O objetivo desta pesquisa é caracterizar as relações interpessoais estabelecidas por adolescentes em medida socioeducativa de internação, a partir da perspectiva dos adolescentes. Trata-se de um estudo de múltiplos casos conduzido por meio de quatro grupos focais com 25 adolescentes, entre 15 e 19 anos, internos em unidades socioeducativas de dois Estados brasileiros. Os participantes caracterizaram as relações com os funcionários como hostis e distantes. As relações com os pares parecem mediadas por valores que perpetuam a conduta infracional. Os adolescentes relataram aproximação com a família, por se constituírem como fonte de apoio social frente à situação de adversidade. A internação se constitui, assim, como um período de intenso sofrimento e pouco efetivo na função de promover o desenvolvimento.
\end{abstract}

PALAVRAS-CHAVE: adolescente, adolescente em conflito com a lei, adolescente institucionalizado, medidas socioeducativas, relações interpessoais

The objective of this research is to characterize the interpersonal relationships established by juvenile offenders at treatment facilities from their own perspective. The theoretical starting point was the National System of SocioEducational Assistance (SINASE), which establishes the socio-educational measure (MSEs) - judicial measures directed at juvenile offenders in Brazil. SINASE became federal law in 2012 (Brazil, 2012b), subsidized by a technical-operational resolution of 2006 (Brasil, 2006). Resolution and law set guidelines for the MSEs to be executed by means of a restorative approach. From this perspective, interpersonal relationships established in this context should catalyze positive and healthy change processes.

SINASE proposes a type of participatory management whose "major objective to be achieved is the socioeducational community" (Brazil, 2006, p. 41), composed of adolescents and employees of the assistance programs. The socio-educational community should operate in a supportive way, enabling the development of a community sense among its members. Actions should ensure the participation of all, in a horizontal, democratic, and transparent manner,

\footnotetext{
* Financial Support: Capes and CNPq.

** Paper derived from the first author's master's dissertation, advised by the third and the fourth author.

*** E-mail: viniciuscoscioni@gmail.com

n Submetido: 15/01/2018; Revisado: 02/06/2018; Aceito: 17/07/2018.
} 
which favors the effectiveness of the program and its socio-educational character. MSE programs should also ensure family participation, which, in the MSE in treatment facilities, is minimally manifested through family visits.

The composition of the treatment facilities' staff foresees the placement of employees occupying managerial, technical and socio-educational functions. Managers should deal with administrative actions, while the others coordinate the MSE from daily contact with adolescents. The technical staff must be multidisciplinary and has the function of welcoming and accompanying adolescents and their families. Its performance should be based on the specific knowledge of a given professional area, such as psychology, social assistance, pedagogy, and so on. Socio-educational agents have the simultaneous function of preserving the physical integrity of adolescents and staff, as well as developing educational activities, even professional ones. The performance of this function does not require higher education certification (Brazil, 2006, 2012b).

Pedagogical guidelines for socio-educational assistance are defined by SINASE (Brazil, 2006) as a way to guide the actions of employees working with adolescents. As competent authorities, employees should direct their actions from a democratic perspective that ensures the active participation of adolescents. Activities should be designed to make the adolescents meet a number of demands as a way of developing their potential skills and abilities, but without disregarding their limitations. The constructive, supportive, favorable, and creative presence of employees is also highlighted, and they should educate from personal example.

A systematic review of the literature (Coscioni, Costa, et al., 2017) characterized the fulfillment of the MSE of confinement in Brazil from the analysis of 30 studies conducted in treatment facilities. The main conclusions of the review on interpersonal aspects reported were: (a) the interpersonal climate at the facilities is marked by hostility between adolescents, and adolescents and staff; (b) there are friendly interpersonal relationships between adolescents and staff, albeit less frequent and seen as exceptions; (c) coexistence among adolescents generates an in-group culture, characteristic of adolescents submitted to MSEs; (d) adolescents give importance to the family and strengthen the bond with their families during confinement, and (e) family visits occur precariously due to logistical issues at the facilities, besides mistreatment by the employees.

Regarding relationships with socio-educational agents, research has revealed a pattern of authoritarian relationship. Adolescents interviewed in studies in Pernambuco (Monte \& Sampaio, 2012) and Rio de Janeiro (Oliveira, 2003) identified that agents treated them with abuse of power, expiatory punishment, and even physical violence. A multiple case study compared two treatment facilities in Minas Gerais (Menicucci \& Carneiro, 2011), and identified the indiscriminate use of sanctions by agents of both institutions. The research indicated that, although the facilities had rules of procedure, employees followed regulation in the face of unforeseen events from their interpretations and convictions. In a study in São Paulo (Lazaretti-da-Conceição \& Cammarosano-Onofre, 2013), the adolescents interviewed also reported the excessive use of isolation practices by agents. Elements of positive relationships were found in a case study in Rio de Janeiro (Oliveira, 2003), whose participant reported a differentiated relationship of social support and intimacy with a local agent. The participant added, however, that the agent was warned by his superior not to tighten ties, since this was not his job as an employee. Adolescents interviewed in Porto Alegre (Branco \& Wagner, 2009) identified socio-educational agents as playing the role of counselor, social regulator, and emotional support.

With respect to the technical staff, research identified institutional elements that hampered bonding with adolescents. In a research in Rio de Janeiro (Oliveira \& Assis, 1999), technicians claimed that due to overwork, they had to write reports based on few numbers of assistance meetings. In addition to the precarious investments in human and material resources, overwork undermined the quality of both functions: technical assistance and evaluation. Adolescents interviewed in Porto Alegre (Coscioni, Farias, et al., 2018) identified that the main function of the technical staff was to write reports submitted to the Judicial Power, which directly interfered with their interpersonal relations. In a study in the Federal District (Souza \& Costa, 2012), the researcher observed attempts by the technical staff to conduct their duties in accordance with SINASE, which was hampered by the precariousness of human and material resources.

Among the studies related to socialization among adolescents submitted to the MSE, ethnographic studies that investigate their rules of socialization and values (Almeida, 2013; Aragão et al., 2012; Mallart, 2014; Neri, 2011) prevail. These studies found a kind of collective pact that regulated interpersonal relations as a way of ensuring order in the place. Two of these studies (Mallart, 2014; Neri, 2011) focused mainly on investigating the power of criminal factions, and identified the dominance of these groups at the facilities. In a case study in Rio de Janeiro (Oliveira, 2003), the participant revealed to have suffered sexual violence by other inmates, who did not accept the fact that he had committed rape. In another research (Silva \& Ristum, 2010), teachers of the socio-educational system revealed that the adolescents had an intimidation posture, from which there was a kind of dispute for power at the place.

Regarding relationships with family members, the studies converged to identify appreciation of the family during the confinement period. In a study in Minas Gerais (Souza 
\& Menezes-Santos, 2010), the participating adolescents considered family visits as the best moments experienced during their deprivation of liberty. Family members interviewed in Rio Grande do Sul (Dias et al., 2011) and Distrito Federal (Souza \& Costa, 2013) recognized that the period of deprivation of liberty favored (re)approach with their children. Another study in Rio Grande do Sul (Branco $\&$ Wagner, 2009) found that the social networks of the five participants included almost all family members. A study conducted with family members in Rio Grande do Norte
(Medeiros \& Paiva, 2015) verified a context of violation of the rights to family visits, which made it difficult to comply with the right to interaction with the family.

Different from the studies presented, this research intends to give a greater role to adolescents in reporting interpersonal relationships experienced with different groups of people within the treatment facilities. In this sense, its purpose is to characterize the interpersonal relationships established by juvenile offenders at treatment facilities from their own perspective.

\section{METHOD}

This is a multiple case study (Stake, 2006) considering focus groups of juvenile offenders at treatment facilities as case units.

\section{Participants}

Twenty-five adolescent inmates participated in the study in four treatment facilities in Cariacica, state of Espírito Santo (ES), and Porto Alegre, state of Rio Grande do Sul (RS). The choice of participating institutions considered the age of the adolescents assisted, taking into account that in each city there should be one group whose members were between 15 and 17 years old and another with members between 18 and 20 years old. Participants were recruited with the help of the treatment facilities' employees, considering the following inclusion criteria: (a) submitted to the MSE for more than six months (reasonable time to bind with other people), and (b) receiving family visits (the research investigated family relationships). No adolescents who had a history of interpersonal conflict were recruited. The adolescents who accepted to participate in the study described themselves as predominantly brown (six participants in each region), with predominance of black adolescents in ES (three in ES and one in RS) and white adolescents in RS (six in RS and three in ES). Most of them were in elementary school (21 in ES and 20 in RS). The fictitious names were suggested by the participants or based on characteristics observed.

\section{Instruments}

The research was conducted from focus groups, based on a script of semi-structured activities that established two sessions. In the first session, the participants and the research team produced identification badges and introduced themselves. In a second moment, the participants' life projects were discussed. The second session began with the debate about interpersonal relationships established with technical staff, socio-educational agents, family, and peers during confinement. The contributions of these relationships to the elaboration of life projects were then investigated. The focus of the article is on the initial content of the second session, and the other contents were analyzed in other manuscripts (Coscioni, Marques, et al., 2018; Coscioni, Nascimento, et al., 2018).

An identification form, an observation protocol and a field diary were used as complementary instruments. The identification form contained bio-sociodemographic and socio-educational data. The observation protocol was systematized and delimited a set of behaviors presented by the participants during the activities: voice intonation, interactions, changes of opinion, and insights. The field diary was also systematized (Coscioni, 2017) and referred to infrastructural and institutional aspects, as well as interpersonal aspects observed during fieldwork.

\section{Data Collection Procedure}

The focus groups met between March and April 2016 and each of their sessions lasted approximately two hours. The activities took place in rooms at the treatment facilities, varying according to the location: cafeteria, library, pedagogical space, and classroom. All spaces were free from employees and other adolescents. Each group had six participants, except for one in RS, which was compose of seven adolescents. The groups were conducted with one mediator, one co-mediator and two observers - one completed the observation protocol, while the other recorded the participants' speech sequence. The role of mediator was played by the same person, but the rest of the team was different in each of the regions. The mediator was 26 years old and a master's student in psychology. The co-mediators were doctoral students in psychology, between 30 and 35 years old, female in ES and male in RS. Observers were from 22 to 32 years old and of both genders. No research team member met the participants before data collection.

The adolescents were accessed individually after the group gathering, and they were offered the possibility of bringing contents that had not been expressed collectively. The adolescents were also contacted after partial data analysis, between December 2016 and January 2017. In this sense, only the adolescents still living in the treatment facilities were interviewed, and the objective was to access 
the adolescents' opinion about the partial results. These individual meetings were also held by the focus group mediator in rooms at the treatment facilities.

\section{Data Analysis Procedures}

Focus groups and interviews were transcribed and their content was treated, along with field diaries, through Thematic Analysis (Braun \& Clark, 2006). With the help of NVivo 11 software, the sections relevant to the objective proposed were coded and grouped by semantic similarity. From these groupings, themes and sub-themes were created a posteriori, through emic approach, that is, according to the participants' own perspectives (Olive, 2014). These thematic units have been revised to the extent that all codes have been entered into mutually exclusive categories. The themes were named, described, and presented to a second judge, who accessed the data and codified the passages considered relevant in a priori categories, that is, the themes created by the first judge. Differences were addressed by consensus. Both judges participated in the data collection and had professional and research experience with juvenile offenders. The first judge was the mediator of all groups, while the second was co-mediator of the groups in ES.

Systematic procedures based on Stake (2006) were used to identify similarities and differences between cases. To this end, protocols were created from which the different semantic manifestations of the thematic units in each group were identified. These different semantic manifestations were compared between the groups and their similarities and differences were articulated to the contents recorded in the field diaries and observation protocols. The two judges worked together at this stage, and the differences were also treated by consensus. The focus of the analysis was related more to the beings than to the cases, which directly interfered with the presentation of the results. In this sense, rather than emphasis on the description of the cases, the focus was on how the beings appeared in the cases (Stake, 2006). Finally, SINASE (Brazil, 2006; 2012b) and previous research findings were used to elucidate the results.

\section{Ethical Procedures}

The research was reviewed by a research ethics committee and based on Resolution No. 466/2012 of the National Health Council (Brazil, 2012a), in force at the time. Its objectives, justification, procedures, and ethical criteria were presented to the directors of the socio-educational systems and to the technical and managerial staffs of the facilities. The adolescents met the research team individually prior to data collection in order to receive information to ensure free and informed consent (Coscioni, Dias, et al., 2017). By voluntarily agreeing to participate, the adolescents signed the Informed Assent Form (or the Informed Consent Form, depending on age). Site managers signed the term for teens under 18 year of age.

\section{RESULTS AND DISCUSSION}

The analysis generated 10 themes, described in Table 1. The themes will be discussed in subsections that reflect on the interpersonal relationships established with each group investigated (socio-educational agents, technical staff, peers, and family).

\section{Socio-Educational Agents}

Participants criticized the way socio-educational agents worked, noting the lack of interest in performing routine activities, as well as bias in the exercise of their functions. They stated that agents complained about the work, sometimes failing to perform their duties: "When they are upstairs, they've got lot of stuff to do, but they don't want to work. They want to stay there poking the pooch, having coffee" (Quizzer, 18 years old). They revealed that their opinions were little considered in daily life: "That's the real deal, you know, as they tell us over here, our word means nothing for them" (Honest, 18 years old). They also complained about how they were submitted to disciplinary sanctions indiscriminately:
One of these days, the guy just took the remote control, and placed it on the other table. The woman, the other agent, asked for the remote control. He told her to wait cuz he was about to change the channel. Then she sent him to isolation for two days. Changing the channel is not a reason for being sent to isolation. (Edgy, 16 years old)

The indiscriminate use of disciplinary sanctions is a violation of law and an unfavorable practice for healthy development. SINASE (Brazil, 2012b, Art. No. 71) states that social and educational entities should systematize a disciplinary regime, discriminating and typifying the infractions subject to sanctions. The adolescent is also ensured the right to a broad and contradictory defense, and application of sanctions not previously discriminated in the disciplinary regime is prohibited (Brazil, 2012b, Art. No. 75). In view of the pedagogical principles expressed by SINASE (Brazil, 2006), it can be thought that other forms of conflict resolution should be encouraged among socio-educational agents, based on mutual respect and "education by example." Isolating adolescents without any legal or pedagogical prerogative seems to indicate 
Table 1

Summarized description of subjects generated in data analysis

\begin{tabular}{|c|c|}
\hline Subject & Summarized description \\
\hline $\begin{array}{l}\text { Evaluative Technical } \\
\quad \text { Function }\end{array}$ & $\begin{array}{l}\text { The technical staff has the function of evaluating the adolescents. This assessment occurs to investigate the } \\
\text { adolescents' aspirations. Adolescents are not comfortable sharing this content with the technicians, fearing that it may } \\
\text { mean increased length of stay at the facility. This leads adolescents to simulate behaviors and omit information in } \\
\text { order to convince techinical staff in relation to extinction of the MSE. }\end{array}$ \\
\hline $\begin{array}{l}\text { Disbelief at the } \\
\text { technical staff }\end{array}$ & $\begin{array}{l}\text { The technical staff demonstrates not caring about the adolescents, taking a judgmental posture as well as transmitting } \\
\text { fake news. Technical meetings are often repetitive, occur at a low frequency, are ineffective and do not help } \\
\text { adolescents. }\end{array}$ \\
\hline Technical staff support & $\begin{array}{l}\text { The technical staff works effectively and helps the adolescents from the transmission of information, help with daily } \\
\text { activities, and intermediation in relation to contact with the family. Adolescents consider positive the meetings in } \\
\text { which technicians do not ask so many questions, give advice, and demonstrate understanding of their points of view. }\end{array}$ \\
\hline $\begin{array}{c}\text { Authoritarian } \\
\text { Socio-Educational Agents }\end{array}$ & $\begin{array}{l}\text { The opinion of socio-educational agents prevails over adolescents' opinion. As a result, agents submit adolescents to } \\
\text { indiscriminate sanctions, physical aggression, humiliation and humiliating and embarrassing procedures. }\end{array}$ \\
\hline $\begin{array}{l}\text { Good coexistence with } \\
\text { socio-educational agents }\end{array}$ & $\begin{array}{l}\text { Adolescents and agents establish an intimacy relationship. Agents advise adolescents, talk about their daily and family } \\
\text { issues, submit them to few sanctions, give tips not to get involved in conflicts that can mean sanctions, act kindly, and } \\
\text { do favors that help them with their daily lives. }\end{array}$ \\
\hline $\begin{array}{l}\text { Rules of coexistence } \\
\text { among adolescents }\end{array}$ & $\begin{array}{l}\text { The adolescents live with rules that were created between them and that exist in the institution for generations. These } \\
\text { rules establish a collective pact. The main rules refer to the treatment of family members. Punishments are due to the } \\
\text { violation of these rules, involving physical aggression and isolation. Adolescents who have committed sex offenses } \\
\text { are also isolated from the others }\end{array}$ \\
\hline $\begin{array}{l}\text { Disagreements and } \\
\text { coexistence with the enemy }\end{array}$ & $\begin{array}{l}\text { There are quarrels among adolescents, motivated by belonging to rival criminal factions, unwanted play, and personal } \\
\text { quarrels. As adolescents have in common the desire to leave the facility as soon as possible, they agree that problems } \\
\text { before and during confinement should be resolved after being dismissed from the MSE. }\end{array}$ \\
\hline $\begin{array}{l}\text { Friendship and solidarity } \\
\text { among adolescents }\end{array}$ & $\begin{array}{l}\text { Adolescents establish friendships, especially with members of friendly criminal factions or of the same dormitory. } \\
\text { With these adolescents, there is advice exchange and even protection against conflicts with other adolescents. } \\
\text { Adolescents share materials they receive from their families during visits. }\end{array}$ \\
\hline Importance of the family & $\begin{array}{l}\text { Adolescents consider the time of family visits the most important and enjoyable during confinement, creating } \\
\text { expectations for their occurrence and feeling sad after family members go away. Through visits, the adolescents } \\
\text { get information about the environment outside the facility, showing dissatisfaction when family members omit } \\
\text { information. The period of the MSE provides the approximation of adolescents with their family, and adolescents who } \\
\text { do not receive visits commonly face more difficulties during the MSE. }\end{array}$ \\
\hline $\begin{array}{l}\text { Difficulties in contacting } \\
\quad \text { family members }\end{array}$ & $\begin{array}{l}\text { Adolescents report situations that hamper contact with their families during the MSE. Logistics issues of treatment } \\
\text { facilities delay family members from entering at the expected visit time, then lines are formed for visitors to enter. } \\
\text { Employees abuse family members, who undergo embarrassing inspection procedures. Telephone contact with family } \\
\text { members is difficult and very short. Visitors spend a lot of money with bus tickets and cleaning products and food. } \\
\text { The space for visits is insufficient to accommodate all present and there is no place for intimate visits. Visits to family } \\
\text { members in prisons are hampered by bureaucratic procedures and occur in an embarrassing way. }\end{array}$ \\
\hline
\end{tabular}

the application of the MSE from a coercive logic. Other participants' statements exemplify actions of agents distant from their pedagogical purpose, even using humiliating procedures:

User (17 years old): They punch us, they use handcuffs on us. They do like this, you know, they hold your nape and do like this... [He lowers his head to the floor] / Edgy (16 years old): They put the guy on the floor. / Anxious (17 years old): You have to be like this. / User: As far as he wants. If he wants to walk the whole facility, you will walk the whole facility. I Edgy: Four, five hours like this. / Anxious: Seated. / Edgy: Thrown back, looking at the floor. / Mediator: Handcuffed with hands behind back, looking at the floor? / User: Without lifting the head. / Edgy: And sometimes he wants you lying, looking at the floor and legs up. / Mediator: Lying, and face on the floor? / Edgy: Something like this, he puts us with the chest on the floor, handcuffed with hands behind our back and legs up. You cannot put legs down. If you put legs down, he will carry you again.

The results suggest that relations with socio-educational agents are hostile, marked by physical and psychological violence and inhuman treatment. Other Brazilian studies have observed similar results (Lazaretti-da-Conceição \& Cammarosano-Onofre, 2013; Menicucci \& Carneiro, 2011; Monte \& Sampaio, 2012; Oliveira, 2003), and such hostility seems to be a common element in the MSE system. This reality goes against the principles of SINASE (Brazil, 2006), according to which employees should educate by personal example. Assaulting, humiliating, and isolating are coercive methods that are far from the pedagogical proposal of the MSE. Socio-education should start with 
employees, who, assuming a positive example, can catalyze change processes.

Mentions on violence were more frequent in ES. Records in the field diaries observed a strong focus on safety procedures, which may relate to the socio-educational agents' self-perception as security professionals. Eight months after the group has met, Edgy (16 years old) revealed changes in the treatment by agents at the facility. According to the participant, after installation of cameras, physical aggression occurred less frequently, due to the possibility of denunciation. The adolescent believed that such changes were also related to change in management.

Reports of physical aggression were absent among participants of one of the facilities in RS, recognized for its violence-free assistance policy. Records in the field diary revealed an interpersonal climate of greater friendliness. In addition, one of the shift chiefs informed a research team member that for a long time he did not believe in the pedagogical function of his work, performing it solely for economic reasons. The employee added that, over time, he began to identify more with the socio-educational principles expressed by law, effecting changes in the way of acting with adolescents. He added, however, that such a position was still rare among his colleagues. He attributed the fact to the lack of training among employees, which could lead to an understanding of the current principles for socio-educational assistance.

The way coercive and socializing logics are articulated in the context of the application of the MSE is associated, among other aspects, with the employees' view on the service policy (Menicucci \& Carneiro, 2011). The emphasis on security seems to lead socio-educational agents to a perception of themselves as security officials. Continuing education can promote improvements in the organizational and interpersonal climate, thus favoring a process of new social insertions for adolescents.

Participants stated that they developed greater affection in relation to some agents, characterized as willing to help and working in a humane manner:

Frank (19 years old): He talks to us, he checks if everything is ok and asks if we need something. / Humble (19 years old): He knows how to talk to you, right? He makes you stay calm, he advises you to change your life. / Frank: He says that wants to see us different when we get out of here. He no longer wants to see us over here. / Quizzer (18 years old): They do what they have to do; they search for other ways, which is what we were talking about. Then, if we ask for something, they do it. They may not do it at that time, but they have their reasons for not doing it at that time / Humble: Some people don't even eat to do us a favor.

Participants considered the humanized treatment by these agents favorable to the socio-educational process. There were reports of agents showing concern, associated with a positive demand, which led to reflections and changes: "They treat you well, but they are very demanding, you know? They want to see you well" (Zeus, 16 years old). Such conduct is congruent with the principles of SINASE (Brazil, 2006), according to which employees should take a "demanding and understanding" attitude that leads the adolescent to a healthy development. Other Brazilian studies have found reports of positive relationships with agents, described as exceptions in a climate of hostility (Branco \& Wagner, 2009; Oliveira, 2003). Good treatment by agents was most often described by adolescents who referred to themselves as more polite:

Here, the monitors treat me very well. They say I am a polite person. I know how to talk to people, I know how to say "please," "yes, sir," "no, sir." I think it is because that they treat me in a different way. (Honest, 18 years old)

Smaller repertoire of social skills thus seemed to relate to a more violent way of treatment. Such differentiation is inadequate to the principle of fairness in treatment (Brazil, 2006, 2012b), since adolescents with small repertoire of social skills need special attention due to their vulnerable condition.

The results suggest that humanized treatment by some agents is consistent with the principles of SINASE (Brazil, 2006), and leads to healthy development. Efforts should be made to transform this pattern of relationship into the rule rather than the exception. The prevalence of violent relationships seems to reflect a culture of confinement that has followed criminal institutions since their origin (Foucault, 1975/2011). It is necessary to break with this culture and provide adolescents with a space in which their physical integrity is ensured, and interpersonal relationships favor new social insertions.

\section{Technical Staff}

The adolescents understood that the main function of the technical staff was to write the reports that supported the MSE re-evaluation hearings, so that the purpose of the technical meetings was to collect information to be transmitted to the Judiciary Power. In this context, participants said they omitted information, fearing that it would mean increased length of stay: "The guy feel kind of threatened cuz they ask him all the time if he will change or not. He's afraid to say he won't change. Then, he has to lie" (Troublemaker, 18 years old). The adolescents revealed that they even simulated behaviors in order to convince the technical staff that they should receive an MSE progression:

Honest (18 years old): It is like we talk among us: "I was attended by the technician and I entered her mind." The guy has to involve the person a lot.... I don't know if they pretend to believe us, but it seems they do. / Mediator: What would "enter her mind" be? / Honest: Enter the mind.... Something 
like that, if the guy says he will quit crime and is calm, it is easier to get out [end of the MSE]. If the guy has to cry at the meeting, to affirm that he is sorry....

The evaluative function assigned to the technical staffs is incongruent with their pedagogical function. SINASE (Brazil, 2012b, Art. No. 42, § 1) establishes that the MSE reevaluation hearing shall be instructed by a report from the technical staff of the MSE program. The purpose of this document is to describe the evolution of the Individual Assistance Plan, built with the adolescent during the MSE. In this sense, the activities developed should be reported with a view to understanding how the MSE program has managed its pedagogical process. Misuse of socio-educational technical reports has been observed in other studies, whose results revealed decontextualized reports that individualized adolescents' misconduct or blamed their family members (Malvasi, 2014; Medeiros \& Paiva, 2015; Scisleski et al., 2015). Thus, the participants understood that the relations between adolescents and technicians would be different if there was no evaluative function:

Mediator: Let's suppose that the technical staff no longer have the function of writing your report. How do you think your relationship with the technicians would be? / Frank (19 years old): I think it would be more truthful, you know? More sincere, you know? / Quizzer (18 years old): We would talk more freely and would not be prejudiced. Well, you are psychologist [referring to the Mediator], I cannot talk to the psychologist of the facility about what I talked to you today, or yesterday. So, it's different, cuz a lot of things we talk about compromise us.

From the records in the field diary, it was observed that the employees disagreed with the way they performed the function of writing the reports. They stated that they felt pressured by the Judiciary Power to take a position on the sentence related to the MSE, which undermined the establishment of more authentic relationships. The constant need to write reports caused a decrease in assistance. Small contingent of staff and overcrowding aggravated the situation, as each technical staff became responsible for accompanying too many adolescents.

The records in the field diary revealed that the precariousness of the physical structure also interfered with the frequency with which adolescents and techinical staff met, and there was even lack of space for the meetings. The treatment facilities in RS were in worse state of precariousness, with reports of meetings taking place in cafeterias and classrooms. This may be related to the higher frequency of reports on the low frequency of assistance meetings among adolescents in RS. In the state of ES, Edgy (16 years old), interviewed eight months after the focus groups, revealed that the meetings started occurring more frequently. The adolescent associated this change with the reduction in the number of adolescents, as well as with the change of management in the place.
The results suggest that relations with techinical staff seemed to be influenced by the precariousness of human and material resources. The Executive Branch seems to be accomplice in such logic, since there is a lack of investments in MSE programs - which leads to the privatization of work and infrastructure of the assistance entities. The Judiciary Power also contributes to the precariousness of work, due to the accumulation of judicial demands that hinder the performance of pedagogical activities - either by overwork, or by institutional aspects that assign the role of evaluating adolescents to the technical staff. A similar state of precarious work was found in other Brazilian studies (Coscioni, Farias, et al., 2018; Oliveira \& Assis, 1999; Souza \& Costa, 2012), which leads to the understanding that this is a national reality.

This context of impoverishment of public policies seems to be related to the participants' statements telling that some technicians worked partially, and assumed a judgmental position:

She comes and says that nobody is ready to go to the conclusive [phase]. Then, you ask "And my case, my report?" And she asks "what is your accusation?" "homicide." And she "three years is a short time for you." How do you think the guy feels when listening to it? Do you think he will want to change when she talks like this? (Frank, 19 years old):

The attitude adopted by the employee in the above report is in complete disagreement with the principles of SINASE (Brazil, 2006, 2012b), and negatively impact the self-esteem and motivation of adolescents in their socioeducational process. By assuming a conduct of judgment, the technical staff hampers its connection with the adolescent and denounces the influence of punishment discourses in which the role of the MSE is to punish rather than educate.

Albeit predominantly distant, the adolescents described positive relationships established with the techinical staff, characterized by trust and psychological support:

Thinker (16 years old): They get involved, something that is not their work, but they end up getting involved. / Mediator: What do you mean with "they get involved"? Could you explain better? / Thinker: They get involved, follow the guy's family to know what happened, and stuff. It is not their work. Their work is only to help me get out of here. They don't have to get involved, don't have to judge, don't have to say a word. They have to write the report to the Judge, and that's it.

The above statement suggests that the pedagogical functions of the technical staff were seen by the adolescents as favors, prevailing the understanding that their main function was to write reports to the Judiciary Power. Moreover, the relationships of greater intimacy between adolescents and techinical staff were more frequently reported by adolescents who called themselves 'more polite' and showed greater interest in the activities. The technical staff should be prepared to deal with adolescents with small 
repertoire of social skills, as well as with those who feel unmotivated in participating in the assistance meetings.

The affective involvement presented by some technicians was related to development of social skills, maturity, and future aspirations far from crime. This type of relationship, expressed less frequently, should constitute the standard of relationship usually established, as it is in line with SINASE (Brazil, 2006) and favors healthy development. For this purpose, efforts should be made to improve working conditions in treatment facilities.

\section{Peers}

Participants reported a set of rules that mediated relations between inmates. These rules valued the collective, and the idea of mutual respect prevails:

Every place has its rules. Our rules are about respecting each other, at the visit time, at the dormitory. Just respect. You have to respect the other, cuz if I don't respect him, I allow him not to respect me, right? Our rules are: everyone respecting everyone not to cause confusion, cuz if one is prejudiced, everybody is. (Edgy, 16 years old):

Among the rules, there was effort to avoid fights, since their occurrences brought negative consequences, not only to those directly involved, but to the other inmates. For those directly involved, participation in conflicts could mean increased length of stay from negative evaluation by the technical staff. For others, the occurrence of conflicts could damage the routine at the facility. This was because occurrence of a hostile interpersonal climate hampered the relationship with the employees and, consequently, the evaluation process of all. Adolescents thus agreed that personal problems should be resolved after being dismissed from the MSE, so that adolescents from rival criminal factions should coexist during the MSE:

Bullet Train (18 years old): The guy has to live with others that are against him. / Honest (18 years old): Even being against you, the guys will need your help to do everything, right? I Serene (18 years old): What can you do if they are against you? / Honest: Over here, the guy has to click with the others, right? The guy must learn how to live together. / Bullet Train: Even if I am against you, every day I will wake up and will have to look at your face. / Giggler Killer (18 years old): One is missing in the soccer team, "Oh, I will not play against him." There's no such thing. / Honest: The guy plays. / Bullet Train: The guy plays, there are many against him over here I Honest: The guy may have an argument, a situation. Then, the guy is worked up, but he understands that is about to leave. I Lil' Joe (18 year old): There are guys that are going to meet on the streets and will kill each other, right? / Honest: Sure thing, but over here they avoid it.

The findings differ from the results of an ethnographic research conducted in two treatment facilities in Rio de
Janeiro (Neri, 2011). In Rio de Janeiro's institutions, the adolescents were separated in dormitories according to their connection with criminal factions. Inmates understood that living with the Germans (expression used to refer to members of criminal factions) was inconceivable and could lead to conflict.

Participants described rules aimed at the respect for family figures. It was not allowed cursing family members of other adolescents, nor looking directly at the visits of other inmates. Clothing on visiting days was also regulated: it was not allowed wearing short clothes that showed arms or underwear, nor lifting the $t$-shirt or other part of the garment so as to expose the body. Masturbation was not allowed on visiting days, and for some groups this rule extended to one day before and two days after the visit. The adolescents stated that masturbation could be associated with the image of people who visited them, and it should be avoided as a sign of respect.

Participants revealed other internal rules. There were rules regarding hygiene, regarding the cleanliness of the physical space, as well as personal hygiene to avoid bad odors. It was not allowed talking to others about subjects that were pertinent only to the adolescents. These subjects included: details of internal rules; punishments delegated to people who violate rules; etc. This pact of silence was observed during data collection in one of the facilities in ES, as participants fell silent and looked at each other when controversial issues were addressed. Only in an individual interview an adolescent talked about such topics:

The rule is followed by us. We create the rule, what is allowed and what is not. If there is visit on Sunday, the person cannot masturbate from Sunday to Tuesday. Then the guy.... Sunday comes, Monday comes, and he does it. Someone learns it, and he is punished, and the stuff is among us. No agent has to know it. Or, swearing at someone's mother. This doesn't happen, or you are punished. Colluding with each other doesn't happen either. Fighting doesn't happen. We have always to respect each other. It's not because of fear, but we have to respect cuz we live together. (Anxious, 17 years old):

The adolescents stated that the violation of the rules implied punishments, which were applied in different levels of severity. The transgressing adolescents were excluded from being with the others and had to eat their meals separately. All adolescents should avoid contact with the transgressing ones, since a sign of agreement with the violation would also mean a transgression. Non-compliance with certain rules was punished with milder sanctions. According to the participants of one of facilities in RS, throwing a banana peel on the floor meant non-compliance with the cleaning rule. This would lead to the exclusion from being with others for a week, besides the need for cleaning up the place during this time. Violation of more serious rules could mean more severe punishments. In the same facility, the participants described the situation 
of an adolescent who masturbated on the day of the visit and, for this reason, was excluded from living with others indefinitely. The rules on punishment seemed stricter in this facility, which may be related to the location profile, which included the most complex cases (perpetrators of serious and/or recurrent offenses).

Participants affirmed that adolescents who committed certain offenses were also subject to the same punishments. Sexual offenses and robbery committed against workers were among these offenses. Similar results were found in the aforementioned ethnography (Neri, 2011), whose participants described as scumbags the adolescents who denounced other inmates, those who were homosexual or bisexual, those who committed sexual offenses and/ or acts "against their own family members, community residents, senior citizen, child or bus passenger" (p. 284). The scumbags were also subjected to punishment, which involved isolation and physical aggression.

Similar rules were found in research regarding other states (Almeida, 2013; Aragão et al., 2012; Neri, 2011; Oliveira, 2003), which may mean that this code is a common element in these institutions. According to Almeida (2013), these rules exist as a way to contain the possibility of chaos among inmates who live together. The author analyzed the report of adolescents submitted to the MSE and extracted the idea that there was a conception of the others as essentially evil people, so that rules avoided conflicts that could lead to more serious consequences, such as homicides.

Beyond the rules, participants showed some ambiguity in describing the interpersonal climate among adolescents. Some relationships were characterized by hostility and distrust, and disagreements were reported motivated by belonging to rival factions and disrespect. This climate of tension was similar to relationships with socio-educational agents and was found by research performed in different states (Almeida, 2013; Neri, 2011; Silva \& Ristam, 2010). A climate of intimidation seemed to exist as a survival strategy: "The thing is, over here each one knows what can be done out there, so almost nobody submits to the will of others" (Beholder, 19 years old). This climate of intimidation also generated physical aggression at times:

There are guys that talk to you, but at the same time they give you a hug, they stab you in the back, you know? They wish us bad stuff. And then we will not say "Oh, I wish good things for that guy." How come we will wish good things for the guy if he wishes bad for us, you know? Cuz of this many times we come to blows with this guy and with others. They drive the guy crazy, say bad things about him, and then the guy gets stressed out and starts fighting. (Outlander, 17 years old):

On the other hand, the participants described a set of relationships characterized by peaceful and harmonious coexistence. A climate of solidarity was described, in which adolescents helped each other with advice and emotional support: "Everybody is humble to each other, helps each other. In hard times, this person is there to give advice. If you need support, if your friend can help, he helps" (Edgy, 16 years old). Other studies (Almeida, 2013; Aragão et al., 2012; Neri, 2011) verified that solidarity extended to exchanges of cleaning products and food that were taken to the places during family visits. In this sense, adolescents who did not receive family visitors had help from other inmates who received family members. This type of relationship was more common among adolescents of the same faction and dormitory, which resembled a friendship relation:

There is always someone who is closer to you, someone you have more intimacy to talk to. Many times, he feels your pain and wants to help you when you are suffering. If you are in a bad situation, he gives you advice, helps you, and vice-versa. So, I cannot say that my relation with one guy is the same that with the other guy, and vice-versa. There will always be someone that is closer to you, and you will talk to this person about things you don't talk to everybody. (Quizzer, 18 years old):

This friendship relation was most mentioned among the participants of the facility in RS, recognized by the violencefree assistance policy. This may relate to less visible effects of institutionalization, enabling more authentic interactions.

Even with rules to prevent conflict between inmates, the interpersonal climate among adolescents seemed prevalently hostile. These relationships are in disagreement with the principles of the socio-educational community (Brazil, 2006), according to which there should be an incentive for solidarity among inmates. Solidarity was mentioned by the participants but linked to associations with criminal factions. The results therefore suggest that peer relations lead to internalization of ideals linked to the world of crime, so that the period of confinement seems to contribute more to the maintenance of those ideals than their extinction. The MSE, in this sense, ends up promoting the perpetuation of involvement in criminal acts, becoming what is popularly recognized as a school of crime.

\section{Family}

Family visits were described by participants as the best moments experienced during their deprivation of liberty, with expectations for their occurrence:

Mediator: And how is the visit time? / Lil' Joe (18 year old): It's sacred. / Bullet Train (18 years old): It's sacred, it's calm. / Honest (18 years old): The guy takes the chair and.... / Bullet Train: It's a moment....the guy... Giggler Killer (18 years old): The guy feels comfortable. / Bullet Train: Eh, and he gets out of this place... / Honest: The guy wants to know the news. / Bullet Train: It's a moment where the guy gets out of this place, he doesn't live only in the same things. But, it is a short time, right? 
The moments after the visits were characterized by negative feelings, such as missing family and desire to leave the treatment facility in the company of family members:

Disturbed (19 years old): We go upstairs and stay there locked, the family left, only thoughts stay with us. /Humble (19 years old): Eh, when the visit goes away and we have to go upstairs. /Frank (19 years old): We suffer.

Participants also revealed that they approached their family members during the MSE, and there was an affection relationship that they did not have before confinement.

Giggler Killer (18 years old): It was difficult for the guy to tell his mom that he loved her. / Bullet Train (18 years old) Eh, the guy didn't talk about stuff he talks about over here. Here, the guy talks about lots of stuff that he never imagined he would talk about. / Bullet Train: The guy talks even about the bad stuff, the bad things he did. He tells everything. / Giggler Killer The guy's mom didn't even know that he did a lot on the skid row, and then she knows it over here. / Honest: I will try to get out of here and be the same way, stop by for a chat.

The results are corroborated by previous studies (Branco \& Wagner, 2009; Dias et al., 2011; Souza \& Costa, 2013; Souza \& Menezes-Santos, 2010), which converge to identify the value of contact with the family during confinement. It seems that, in the midst of adversity, adolescents see their relatives as a source of support, which motivates some to break with their misconduct and review their future. According to participants, the main source of support is their mothers, which was also highlighted in other studies (Branco \& Wagner, 2009; Medeiros \& Paiva, 2015). The presence of family figures can be understood as a protective factor for adolescents. Participants' statements corroborate this understanding that adolescents who did not receive visits tended to engage in more conflict, which was related to being revolted over the absence of their family:
The family doesn't visit the child, the mother doesn't visit the child, do you think he's gonna be calm in here? Do you think he is going to succeed when listening to her: "Now, you are under arrest, you are on your own, I don't want to see you'? Do you think it will help him? It may help, but it will very difficult to see him saying: "No, I don't want to go through this situation anymore." Most of times the guy gets revolted, right? (Quizzer, 18 years old):

Although participants highlighted the positive effects of family members during the MSE, a few problems are identified as unfavorable to family meeting. In the state of Rio Grande do Sul, adolescents complained about maltreatment by employees, as well as humiliating inspection procedures, and some even asked their relatives not to attend the place. According to the report of adolescents interned in ES, long lines were formed on visiting days, which delayed the entry of family members and consequently decreased the time spent together. Participants from both regions revealed that sometimes family members could not attend family visits, either due to financial difficulties or working hours. The fact that family visits assumed the (originally state) function of providing toiletries and food made family visits a high financial investment. This disrespect for family meeting seems to be a reality in the Brazilian MSE system, given that research conducted in other states (Medeiros \& Paiva, 2015; Souza \& Costa, 2013) observed similar results.

Family meeting is safeguarded by SINASE (Brazil, 2012b) as the right of adolescents submitted to MSE, and the treatment facilities should promote actions that enable family visits. The reality reported by the participants, however, reveals a situation far from that provided for by law, in order to disadvantage family meeting. A state of positive change was reported by participants in interviews conducted eight months after data collection. In the state of Rio Grande do Sul, a more humanized inspection procedure would be implemented, in which family members would not need to be naked in front of employees. In the state of Espírito Santo, family members' entrance became better conducted, optimizing visit time.

\section{FINAL CONSIDERATIONS}

The results contribute to the understanding of interpersonal relationships established by juvenile offenders at treatment facilities. Its differential refers to its emic character and to focus on the processes resulting from the MSE. In previous studies, interpersonal relationships were mentioned mainly as scattered findings, with few investigations whose main objective was to understand the processes of interrelationships with others present during the MSE. Research with employees and family members can help understand interpersonal relationships from the adults' perspective. Longitudinal studies can elucidate how these relationships are established throughout the MSE.
The research brought findings similar to other Brazilian studies, describing a hostile interpersonal climate between adolescents and employees. A culture of imprisonment common to penal institutions is perpetuated in these contexts, favoring even occurrence of violent episodes. The precariousness of human and material resources seems to contribute to the fact that the technical assistance occurs below the legal provision, undermining healthy development. Excessive demands from the Judiciary Power also have a negative effect, given the overwork and the difficulties of connection inherent to the evaluative position that the technical staff now occupies. 
Relations with peers and family members also seem to be influenced by similar institutional aspects. A culture of imprisonment that undermines connection with employees produces an equally hostile interpersonal climate among peers, which reproduce rules that exist at the facility for generations. Stimulated among the adolescents themselves, these rules bring with them elements rooted in the world of crime, in order to perpetuate criminal conduct among adolescents. With regard to the family, such a culture of imprisonment seems to influence the way visitors are treated in these spaces, which discourages visits or negatively interferes with the moments experienced during the visits. The very organization of physical infrastructure should be reconsidered in order to dignify the right to family meeting.

Contextual and institutional aspects related to the MSE need to be reviewed so that confinement could be a period that actually promotes development. The architectural designs of the facilities should be reformulated to fit the legal propositions. Interventions should be designed to perpetuate a new violence-free assistance policy consistent with the principles of a socio-educational community. The relationship between the Judiciary Power and the MSE system needs to be explored in order to regularize the judicial demands sent to the SME technical staffs. Family visits should also be regulated in order to ensure the right of family meeting.

Although positive elements were present in the research findings, they were exceptions in a predominantly hostile environment. The study found that the period of confinement led to the approximation of adolescents with their relatives, which places the family's presence in the MSE as a protective factor. This approach seems to occur, however, as an effect of the experience of adversity, so that the family is recognized as the only source of social support. Participants' reports indicate, therefore, that the MSE is a period of intense suffering, far from the pedagogical logic of a socio-educational community that favors the perpetuation of criminal conduct in the future.

\section{REFERENCES}

Almeida, B. G. M. (2013). Socialização e regras de conduta para adolescentes internados. Tempo Social, 25(1), 149-167. https:// doi.org/10.1590/S0103-20702013000100008

Aragão, E. M. A., Margotto, L. R., \& Batista, R. (2012). Uma cidade-internação e suas multipli(cidades): Encontros com adolescentes em cumprimento de medida socioeducativa. EPOS, 3(2), 1-21. http://pepsic.bvsalud.org/scielo. php?script $=$ sci arttext\&pid=S2178-700X2012000200006

Branco, B. M., \& Wagner, A. (2009). Os adolescentes infratores e o empobrecimento da rede social quando do retorno à comunidade. Ciência \& Saúde Coletiva, 14(2), 557-566. https://doi.org/10.1590/S1413-81232009000200024

Braun, V., \& Clarke, V. (2006). Using thematic analysis in psychology. Qualitative Research in Pshychology, 3, 77-101. https://doi.org/10.1191/1478088706qp063oa

Brazil. Presidência da República. Secretaria Especial dos Direitos Humanos. Conselho Nacional dos Direitos das Crianças e dos Adolescentes. (2006). Sistema Nacional de Atendimento Socioeducativo. CONANDA. http://www.conselhodacrianca. al.gov.br/sala-de-imprensa/publicacoes/sinase.pdf

Brazil. Ministério da Saúde. Conselho Nacional de Saúde. (2012a). Resolução $n^{\circ}$ 466, de 12 de Dezembro de 2012. Diário Oficinal da União. http://bvsms.saude.gov.br/bvs/saudelegis/cns/2013/ res0466 $12 \quad 12 \quad 2012 . h t m l$

Brazil. Presidência da República. Casa Civil. Subchefia para Assuntos Jurídicos. (2012b). Lei federal n. 12.594, de 18 de janeiro de 2012. Institui o Sistema Nacional de Atendimento Socioeducativo. Diário Oficinal da União. http://www.planalto. gov.br/ccivil 03/ ato2011-2014/2012/lei/112594.htm

Coscioni, V. (2017) $)$. Systematization of recording in field diary: A case of a research in Brazilian juvenile detention centers. In Dell'Aglio, D. D. \& Koller, S. H. (Eds.), Vulnerable children and youth in Brazil (pp. 261-274). Springer. https://doi. org/10.1007/978-3-319-65033-3 17

Coscioni, V., Costa, L. L. A., Rosa, E. M., \& Koller, S. H. (2017). $\mathrm{O}$ cumprimento da medida socioeducativa de internação no Brasil: Uma revisão sistemática da literatura. Psico, 48(3), 231-242. https://doi.org/10.15448//1980-8623.2017.3.24920

Coscioni, V., Dias, A. C. G., Rosa, E. M., \& Koller, S. H. (2017). Autonomia e voluntariedade na pesquisa com adolescentes em medida socioeducativa de internação. Revista da SPAGESP, 18(2), 74-85. http://pepsic.bvsalud.org/scielo.php?script=sci_ arttext\&pid=S1677-29702017000200007

Coscioni, V., Farias, B. G., Garcia, A., Rosa, E. M., \& Koller, S. H. (2018). O covívio de adolescentes em medida socioeducativa de internação com a equipe técnica. Psico, 49(2), 137-147. http://dx.doi.org/10.15448/1980-8623.2018.2.27890

Coscioni, V., Marques, M. P., Rosa, E. M., \& Koller, S. H. (2018). Projetos de vida de adolescentes em medida socioeducativa de internação. Ciencias Psicológicas, 12(1), 109-120. https://doi. org/10.22235/cp.v12i1.1601

Coscioni, V., Nascimento, D. B., Rosa, E. M., \& Koller, S. H. (2018). Pressupostos teórico-metodológicos da Teoria Bioecológica do Desenvolvimento Humano: Uma pesquisa com adolescentes em medida socioeducativa. Psicologia USP, 29(3), 363-373. https://doi.org/10.1590/0103-656420170115

Dias, A. C. G., Arpini, D. M., \& Simon, B. R. (2011). Um olhar sobre a família de jovens que cumprem medidas socioeducativas. Psicologia \& Sociedade, 23(3), 526-535. https://doi. org/10.1590/S0102-71822011000300010

Foucault, M. (2011). Vigiar e punir: Nascimento da prisão (R. Ramalhete, Trad.; 39 ${ }^{\mathrm{a}}$ Ed.). Vozes. (Original published in 1975)

Lazaretti-da-Conceição, W., \& Cammarosano-Onofre, E. M. (2013). Adolescentes em privação de liberdade: As práticas de lazer e seus processos educativos. Revista Latinoamericana de Ciencias Sociales, Niñez y Juventud, 11(2), 573-585. https:// doi.org/10.11600/1692715x.1128120912

Mallart, F. (2014). Cadeias dominadas: A Fundação CASA, suas dinamicas e as trajetórias de jovens internos. Terceiro Nome.

Malvasi, P. A., \& Adorno, R. D. C. F. (2014). A vulnerabilidade e a mente: Conflitos simbólicos entre o diagnóstico institucional e a perspectiva de jovens em cumprimento de medida socioeducativa. Saúde e Sociedade, 23(1), 30-41. https://doi. org/10.1590/S0104-12902014000100002

Medeiros, F. C., \& de Paiva, I. L. (2015). A convivência familiar no processo socioeducativo de adolescentes em privação de liberdade. Estudos e Pesquisas em Psicologia, 15(2), 568-586. https://doi.org/10.12957/epp.2015.17659

Menicucci, C. G., \& Carneiro, C. B. L. (2011). Entre monstros e vítimas: A coerção e a socialização no sistema socioeducativo 
de Minas Gerais. Serviço Social \& Sociedade, (107), 535-536. https://doi.org/10.1590/S0101-66282011000300009

Monte, F. F. C., \& Sampaio, L. R. (2012). Práticas pedagógicas e moralidade em unidade de internamento de adolescentes autores de atos infracionais. Psicologia: Reflexão e Crítica, 25(2), 368-377. https://doi.org/10.1590/S0102-79722012000200019

Neri, N. E. (2011) O "convívio" em uma "cadeia dimenor": Um olhar sobre as relações entre adolescentes internados. Revista de Antropologia Social dos Alunos do PPGAS-UFSCar, 3(1), 268292. http://www.rau.ufscar.br/wp-content/uploads/2015/05/ Vol3no1_11.NERI_pdf

Olive, J. L. (2014). Reflecting on the tensions between emic and etic perspectives in life history research: lessons learned. Forum: Qualitative Social Research, 15(2), 1-9. http://www. qualitative-research.net/index.php/fqs/article/view/2072/3656

Oliveira, E. R. (2003). Ensinando a não sonhar: A anti-pedagogia oficial destinada a adolescentes infratores no estado do Rio de Janeiro. Revista Katálysis, 6(1), 85-95. https://periodicos.ufsc. br/index.php/katalysis/article/view/7121

Oliveira, M. B., \& Assis, S. G. (1999). Os adolescentes infratores do Rio de Janeiro e as instituições que os "ressocializam" - A perpetuação do descaso. Cadernos de Saúde Pública, 15(4), 831-844. https://doi.org/10.1590/S0102-311X1999000400017
Scisleski, A. C. C., Bruno, B. S., Galeano, G. B., Santos, S. N. D., \& Silva, J. L. C. D. (2015). Medida socioeducativa de internação: Estratégia punitiva ou protetiva?. Psicologia \& Sociedade, 27(3), 505-515. https://doi.org/10.1590/1807$03102015 \mathrm{v} 27 \mathrm{n} 3 \mathrm{p} 505$

Silva, J. O., \& Ristum, M. (2010). A violência escolar no contexto de privação de liberdade. Psicologia: Ciência e Profissão, 30(2), 232-247. https://doi.org/10.1590/S1414-98932010000200002

Souza, L. A., \& Costa, L. F. (2012). Aspectos institucionais na execução da medida socioeducativa de internação. Revista Psicologia Politica, 12(24), 231-245. https://doi.org/10.1590/ S1413-82712013000200011

Souza, L. A. D., \& Costa, L. F. (2013). A significação das medidas socioeducativas para as famílias de adolescentes privados de liberdade. Psico-USF, 18(2), 277-287. https://doi.org/10.1590/ S1413-82712013000200011

Souza, M. M. S., \& Menezes-Santos, J. A. (2010). O processo de desvinculação de um adolescente com a prática infracional, a partir do cumprimento de medida socioeducativa privativa de liberdade. Pesquisas e Práticas Psicossociais, 5(2), 216226. https://www.ufsj.edu.br/portal2-repositorio/File/...n2/ Souza e Menezes-Santos.doc

Stake, R. E. (2006). Multiple Case Study Analysis. Guilford Press. 